Foreign Exchange Markets, Intervention and Exchange Rate Regimes

Ashima Goyal

Indira Gandhi Institute of Development Research, Mumbai May 2015

http://www.igidr.ac.in/pdf/publication/WP-2015-011.pdf 


\title{
Foreign Exchange Markets, Intervention and Exchange Rate Regimes
}

\author{
Ashima Goyal \\ Indira Gandhi Institute of Development Research (IGIDR) \\ General Arun Kumar Vaidya Marg \\ Goregaon (E), Mumbai- 400065, INDIA \\ Email(corresponding author): ashima@igidr.ac.in
}

\begin{abstract}
While macroeconomic fundamentals determine the exchange rate at long horizons, there are substantial and persistent deviations from these fundamentals. The market microstructure within which they operate, macroeconomic fundamentals, and policies all affect foreign exchange (FX) markets. The paper describes the institutional features of these markets, with special emphasis on the process of liberalization and deepening in Indian FX markets, in the context of global integration. Since the mechanics of FX trading affect exchange rates, they have implications for the appropriate exchange rate regime. First, bounds on the volatility of the exchange rate can lower noise trading in FX markets, decrease variance, improve fundamentals and give more monetary policy autonomy. Second, the speculative demand curve is well behaved under strategic interaction between differentially informed speculators and the Central Bank (CB) when there is greater uncertainty about fundamentals as in emerging markets. So a diffuse target and strategic revelation of selected information can be expected to be effective. Analysis of Indian experience confirms these research results. $C B$ actions, including intervention and signaling, have major effects.
\end{abstract}

Keywords: Foreign exchange markets; intervention; information; exchange rate bounds

JEL Code: F41, G15

\section{Acknowledgements:}

I thank Akash Baikar for research and Reshma Aguiar for secretarial assistance. 


\section{Foreign Exchange Markets, Intervention and Exchange Rate Regimes}

\section{Introduction}

Rapid technological and regulatory changes are altering foreign exchange (FX) markets profoundly, although special features of these markets are likely to survive. Participant profile and behavior is also changing, as technology makes it easier for small parties to access markets anytime and anywhere. The paper reviews these changes, internationally and then domestically. Reforms in Indian markets offer a good case study of the tensions between regulators, markets and technology. The paper also draws out the implications for effective central bank (CB) interventions and for exchange rate policy.

The current consensus from many empirical studies is while macro fundamentals determine the exchange rate at long horizons, there are substantial and persistent deviations largely unexplained by these fundamentals.

A literature on market microstructure of FX markets grew rapidly after seminal work by Lyons (2001). This suggests the mechanics of FX trading has important short-run effects on exchange rates. This is a departure from the traditional modeling strategy of treating foreign exchange rates as a macroeconomic relative price. It also implies it is not only public information which is relevant.

Survey data shows there is considerable heterogeneity in agents' expectations of the future exchange rate. Therefore private information, the transmission of this information, and the relation between information flows plays a vital role. Proprietary information is contained in order flows, which is the net of buyer-initiated and sellerinitiated orders. Although this is a variant of net demand, it is not necessarily equal to zero in equilibrium. Each bank will have knowledge only of its own order flow, which is used to update subjective estimates of the underlying value of the currency.

Order flow is a more precise proxy for expected future fundamentals, since it presents a willingness to back one's beliefs with real money. In specifications that include macro fundamentals and order flow variables, Evans and Lyons (1999) find order 
flow to be a significant determinant of the exchange rate. It performs better than both standard macroeconomic variables, and random walk forecasts.

It follows foreign exchange markets are influenced by a combination of macroeconomic and microeconomic variables. The market microstructure within which they operate, macroeconomic fundamentals, and policies affect the decisions micro market agents make. The Central Bank (CB) is a special kind of agent with special powers and information. So its actions, including intervention and signaling, also have major effects. The Indian experience confirms this.

Other participants in FX markets include banks, non-bank financial companies (NBFCs), merchants and merchant-brokers. Large banks play the role of market makers, accepting both buy and sell quotes. Merchant transactions were originally restricted to trade and other retail transactions involving foreign currency, but now generate many kinds of transactions due to risk management activities. Large and sophisticated corporate treasuries now have multiple FX operations.

The structure of the paper is as follows: Section 2 discusses some institutional features of foreign exchange markets, with a special sub-section and boxes on the process of liberalization and deepening in Indian FX markets. Section 3 draws out implications of varying trader information for exchange rate policy. Section 4 concludes. An Appendix gives some derivations for the model used in Section 3.

\section{Foreign Exchange Market: Institutional features}

Compared to other financial markets, FX markets have unique features ${ }^{1}$. We briefly describe their structure, composition, effects of change in technology and in regulations, then draw out implications for their functioning.

Structure: They are the most liquid markets. Daily market turnover was $\$ 5.4$ trillion in 2013 (BIS 2013). But only about 5 percent of the very large turnover is actually due to customer trade. Decentralized large volume markets with many physically separated market makers, interact through the telephone or private networks, not in a

\footnotetext{
${ }^{1}$ This section is largely based on material in Lyons (2001), Sarno and Taylor (2002), Sagar and Taylor (2007), BIS triennial CB surveys and media reports.
} 
centralized market like a stock market. Decentralization makes FX markets fragmented and less transparent. There is no publicly announced price, and no law requiring disclosure of trades. Each broker or market maker only knows own order flows, with no incentive to share the information. Brokers normally accumulate a subset of market makers' limit orders, and quote the best buy and sell order from a 'book' they keep of such limit orders. A limit order is an offer to either buy or sell a certain quantity of a currency at a certain bilateral exchange rate.

In a stock market clearing-house each party trades with it - doubling the number of transactions. This is known as 'novation'. The identity of the counter-party does not matter since the clearing-house warranties the trade covering its risk through margin payments and deposits. But in an FX market there are many market makers. Market spreads can vary to cover the cost of market- making including counter-party risk ${ }^{2}$. Even if the net position is close to zero, credit limits get filled up, unlike in a clearing house, where only the net position is required for settlement.

Banks that are reporting dealers have to be the market makers in a decentralized market since brokers cannot assess credit worthiness. Identity may be known only after the deal. The direct FX market is double auction and open-bid. That is, two-way prices on both bid and ask are announced to all agents in the market. The brokered market is single auction and limit order. That is, prices are specified only to buy or sell but not both. They are known only to the broker and the party making the offer.

Counterparties, instruments, currencies: Participants are heterogeneous with diverse information sets and reaction speeds, so that profit opportunities can persist for informed traders. Central banks have a special position. Although the interbank market continued in 2013 to account for the majority of transactions (63\%) this share decreased since the nineties because of the rise of other financial institutions including groups such as institutional investors, hedge funds (22\%) and small non-reporting banks $(24 \%)$. Sudden shifts in positioning by large hedge funds that have the fastest reaction speeds and operate with high leverage can magnify shocks to FX markets.

\footnotetext{
${ }^{2}$ Counterparties made large losses as currency volatility spiked after Lehman fell in 2008 . The risk to market makers inventory caused spreads on quotes to increase from 4 to 16 pips. Trade froze for some transactions.
} 
They implement currency programs to secure a notional capital value that may be a benchmark risk free rate.

As the corporate treasury and direct mobile trading FX market grew, traditional brokers were by-passed. But prime brokerage relationships with their clients dominated dealers' trade (16\%) with only $3.5 \%$ driven by trade with retail customers. Corporate treasuries became sophisticated. Customers changed from passive price takers with emphasis on financing and other banking services relating to foreign trade, foreign investors, corporates availing foreign borrowing or involved in mergers and acquisitions, etc. But the share of these non-financial customers in trading fell overall to $9 \%$ in 2013

In April 2013 the US dollar as the dominant vehicle currency was on one side of $87 \%$ of all trades. But renminbi became the 9th most traded currency as turnover grew rapidly to $\$ 120 \mathrm{bn}$. The financial centers UK (with $41 \%$ ), US, Singapore and Japan intermediated $71 \%$ of FX trading. Post GFC bank closures concentrated trading increasingly in the large banks. The ten most active global traders accounted for $77 \%$ of trading volume, of which the top three, Deutsche, Citi and Barclays, were at $40 \%$, according to the 2012 Euromoney FX survey.

OTC turnover at about $95 \%$ share continued to far exceed turnover on exchanges. In 2013 OTC FX swaps were the most actively traded at 42\%, but forwards and options slowed the most rapid growth.

Technology: Although new technologies are causing some change, the majority of transactions continue to be bilateral, occurring in opaque markets without a physical market place. Even so, electronic dealing and brokering systems, are giving some amount of virtual centralization. Electronic Broking System (EBS) or Reuters D3000, established in 1993, accounted for 85 percent of interbank trading by the 2000s.

Electronic systems allow netting, lower settlement and counterparty risk, and have operational benefits such as reducing human error. They provide ex-ante anonymous limit order bid ask pricing to dealers and have driven a large increase in liquidity and reduction in transaction costs. CLS, the continuous link settlement system used by the 
majority of the FX market, settles payment instructions relating to underlying FX transactions in 17 major currencies, reducing settlement risk. The share of inter-dealer trade (39\%) fell as increasing concentration allowed dealers to match customer trade on their own books, and investment in IT infrastructure for warehousing risk reduced the need to offload inventory in the inter-dealer market.

Although voice trading dominates in customer trades, electronic portals are being introduced here also. Electronic crossing networks (ECNs) that aggregate liquidity pools received a fillip from the global financial crisis (GFC). As markets froze, they were successful in finding liquidity where trade could occur without a large impact on price. But electronic systems do not increase the transparency of the FX market since system governing boards treat electronic order flow as strictly confidential. Therefore information on order flow remains divided.

Regulation: It remains to be seen if the regulatory push towards greater transparency after the GFC, which is shifting more over-the-counter (OTC) trade to exchanges, causes a fundamental change. But even the US Dodd-Frank Act that sought to prevent banks' proprietary trading, has given exceptions for the spot FX market, thus accepting that the FX market is different. Higher capital requirements and tighter regulations are, however, reducing banks' participation in all markets.

Despite magnified activity, currency markets remained largely stable during the financial crisis of 2008, partly because risk management procedures had been improved after earlier crises. Banks imposed position limits for individual traders, and risk capital made available was a function of past performance. Incentives to take risk were reduced because losses reduced traders' risk capital while profits were shared with the bank (Geithner, 2004).

But regulation has to continue to evolve in response to new types of malpractices. Since banks often act as principal to a trade, they buy at the moment the client sells. This conflict of interest gives them an incentive to move rates against their customers. Such behavior is difficult in a transparent competitive market since customers getting a poor rate would move elsewhere. But FX markets are not transparent and collusion further removes such protection. In 2014 traders were caught fixing benchmark rates 
to suit their own positions. Employees exchanged confidential client information with rival firms in order to trigger orders against their own customers thus distorting the market. In November regulators from the UK, Switzerland and the US imposed record fines of USD 4.3bn on six large banks whose weak controls allowed these malpractices. More fines followed.

Decentralized currency trading with huge volumes scattered across numerous platforms makes it difficult to monitor and identify dubious trades. Solutions being considered include extending the period during which the daily fixed rate is established to make it harder to manipulate. Big data is being used in creative ways to flag unusual activities. Fines reduce the financial incentive to cheat. They also create pressure on management from bank shareholders. Values set by the top management are also important. Traders caught are normally either dismissed or lose their bonus. There are suggestions for higher penalties include the risk of a jail sentence. Solutions therefore range from better monitoring and incentives to the role of values.

Functioning: More transparency could also be a possible solution. There is some rise in this. More trading on exchanges creates price benchmarks. But is it possible to change the decentralized largely OTC structure of the market with its huge trading volumes? Or does it serve some purpose? Large temporary inventory imbalances generate 'hot potato' trading as dealers iterate towards their optimal portfolios although the share of such inter-dealer trade is falling, it remains very large. Market makers and dealers do not want to carry inventory overnight - which carries inventory risk - therefore they quote ask (buy) and bid (sell) spreads such as to get rid of stocks in the day.

Trades are initiated based on macro data and differential order flow information, with the aim of rebalancing portfolios. The information in the order flow sustains trade. The transactions are not all speculative, or profit seeking. Although this market structure raises the number of transactions, it is less prone to crashes. A centralized system with too many informed traders would crash as liquidity dried up due to 
homogeneous views, especially given the few prices quoted ${ }^{3}$. Compared to the large number of quotes in a stock market, prices in an FX market refer only to a few currency pairs, making the FX market more susceptible to herding and explaining its differential structure.

\subsection{Indian FX markets}

Indian FX markets offer an interesting case study of the process of market development. Intra-day trade was first permitted for banks in 1978, but the market really grew after liberalization ${ }^{4}$, as the Sodhani Committee's (1995) comprehensive blueprint for reform was followed. The Tarapore Committee (2006) also made several recommendations for these markets. Despite major changes in the expansion of turnover and of instruments available for hedging they were still far behind international markets. The advent of electronic trading and communication platforms, reduced transaction costs and risks, and the profile of customers as capital flows became the prime mover of exchange rates. Rising exchange rate volatility, with a more open capital account, increased the necessity for hedging FX risks.

The average daily turnover in Indian OTC FX markets, which was about US \$2.0 billion in 1998, grew to US $\$ 38$ billion in $2007^{5}$. Growth slowed after the GFC, but even so by April 2010 the daily domestic OTC market turnover was $\$ 27 \mathrm{~b}$ and the futures market about $\$ 10$ b. So unlike the global average of $4 \%$ the Indian exchange traded market was about 30\% of the domestic market (Mecklai, 2010b). BIS measures only OTC market turnover. The inter-bank to merchant turnover ratio halved from 5.2 during 1997-98 to 2.3 during 2007-08 reflecting the growing participation in the merchant segment of the foreign exchange market. The spot market remained the most important FX market segment accounting for above 50 per cent of the total turnover. Its share also declined marginally due to a pick-up in the turnover in the derivative segment. Even so, Indian derivative trading remained a small fraction of that in other developing countries such as Mexico or South Korea. Short-term

\footnotetext{
${ }^{3}$ For example Indian FX futures markets grew rapidly, after they were established, but were still thin. If a large party came in on the buy side the sell side would dry up in anticipation of a price rise.

${ }^{4}$ This section, unless explicitly mentioned, updates information in Goyal, Nair and Samantaraya (2009) and Goyal (2015).

${ }^{5}$ BIS (2007) notes this was the fastest rate of growth amongst all world FX markets, although the $72 \%$ rate of growth of world FX market activity between 2004 and 2007 was also the fastest. In the next 3 years growth was $19 \%$ but rose to $35 \%$ over $2010-13$.
} 
instruments with maturities of less than one year dominated, and activity was concentrated among a few non-public sector banks (IMF 2008).

Box 1: Deepening of Indian FX Markets

\begin{tabular}{|c|c|c|c|c|c|c|c|}
\hline \multirow[b]{2}{*}{ USD billion } & \multicolumn{4}{|c|}{$\begin{array}{r}\text { Iable 1.1: Comparison of Indian a } \\
\text { Australia }\end{array}$} & \multicolumn{3}{|c|}{ India } \\
\hline & & 2001 & 2007 & 2013 & 2001 & 2007 & 2013 \\
\hline \multirow[t]{2}{*}{ Daily FX turnover } & Amount & $54(54)$ & $176(220)$ & $\begin{array}{c}182 \\
(462)\end{array}$ & $3(3)$ & $38(24)$ & $31(53)$ \\
\hline & $\%$ & 3.2 & 4.1 & 2.7 & 0.2 & 0.9 & 0.5 \\
\hline \multicolumn{2}{|l|}{$\begin{array}{l}\text { Merchandise } \\
\text { trade, daily } \\
\text { average }\end{array}$} & 0.02 & 1.1 & 1.7 & 0.4 & 1.5 & 2.8 \\
\hline \multicolumn{2}{|l|}{$\begin{array}{l}\text { FX inflow, daily } \\
\text { average }\end{array}$} & 0.02 & 0.07 & 0.14 & 0.02 & 0.26 & 0.16 \\
\hline \multicolumn{8}{|c|}{$\begin{array}{l}\text { Note: (1) Foreign inflows are measured as the current account deficit plus reserve gains. (2) Merchandise trade is } \\
\text { calculated as exports plus imports of goods and services (absolute values) (3) Domestic FX turnover is on net- } \\
\text { gross basis, (that is adjusted for local inter-dealer double counting by subtracting half of the turnover with } \\
\text { reporting local dealers). It includes spot, outright forwards and swap transactions. Global INR turnover is given } \\
\text { on a net-net basis in brackets. This adjusts for local and cross-border inter-dealer double counting by subtracting } \\
\text { half of the turnover with reporting dealers abroad. BIS (2013) warn turnover for years prior to } 2013 \text { may be } \\
\text { under-reported, especially for EMs. } \\
\text { Source: FX turnover calculated from the Bank for International Settlements, various years, for example, (BIS, } \\
\text { 2007, Table E16, pp. 82, http://www.bis.org/publ/rpfxf07a.pdf), the International Financial Statistics (IMF, } \\
\text { various years). }\end{array}$} \\
\hline
\end{tabular}

Table 1.1 shows the rapid deepening of Indian FX markets, the rise in trade and inflows which are dwarfed by the large turnover which itself still remains small even in comparison a middle level developing country like Australia. Table 1.2 shows the shares by types of agents and instruments, with domestic market data from the RBI, and global INR trade (row 8 onwards) from the BIS. With deepening there is a sharp fall in the share of $\mathrm{CB}$ transactions and some rise in derivative use although regulators restraints slowed these after the Euro debt crisis of 2011, but only domestically. Cross border transactions also rose. The share of derivatives is much higher in global INR trade (row 15 Table 1.1) pointing to a large off-shore market. Daily global net-net INR turnover is also higher than domestic FX market turnover (Table 1) 
Table 1.2: Aspects of the Indian FX Market

\begin{tabular}{|c|c|c|c|c|}
\hline & US \$ Billion FCY/INR ${ }^{\mathrm{a}}$ & 2001-02 & 2006-07 & 2012-13 \\
\hline 1 & Total domestic spot turnover (sales + purchases) & 446.1 & 1861.4 & 4525.2 \\
\hline 2 & Total CB intervention (sales + purchases) & 38.6 & 26.8 & 29.9 \\
\hline 3 & 2 as $\%$ of 1 & 8.7 & 1.5 & 0.7 \\
\hline 4 & Share of 1 due to interbank $(\%)$ & 64.5 & 66.3 & 73.4 \\
\hline 5 & Share of 1 due to merchant $(\%)$ & 35.6 & 33.7 & 26.6 \\
\hline 6 & Total forward as $\%$ of total spot & 22.5 & 23.6 & 24.4 \\
\hline 7 & Total swap as $\%$ of total spot ${ }^{\mathrm{b}}$ & 147.4 & 77.2 & 75.1 \\
\hline 8 & Global total INR spot (for April) $(\mathrm{OTC})^{\mathrm{c}}$ & 1.2 & 9.0 & 15.2 \\
\hline 9 & Share due to RDs (from CB survey) (\%) & 51.2 & 63.1 & 45.2 \\
\hline 10 & Share due to other financial insts. $(\%)$ & 9.8 & 18.4 & 38.1 \\
\hline 11 & Share of non-financial insts. $(\%)$ & 39.1 & 18.5 & 16.7 \\
\hline 12 & Share in total spot of local transactions $(\%)$ & 94.1 & 77.2 & 66.9 \\
\hline 13 & Share in total spot of cross border tran.(\%) & 5.9 & 22.8 & 33.1 \\
\hline 14 & $\begin{array}{l}\text { Total domestic FX derivatives as \% of total spot } \\
\text { (net-gross) }\end{array}$ & 116.8 & 137.5 & 102.1 \\
\hline 15 & $\begin{array}{l}\text { Total global INR FX derivatives as \% of total } \\
\text { spot (net-net) }\end{array}$ & 110.9 & 134.5 & 246.5 \\
\hline \multicolumn{5}{|c|}{$\begin{array}{l}\text { Note: Items (1) to (7) were calculated from RBI bulletins. The data was collected for all the months in the given } \\
\text { years and summed up. Each year is taken from April to March. ( } 8 \text { ) to (15) are available in the Central Bank (CB) } \\
\text { Surveys (BIS) and refer to net-net daily averages added up across different participants for April 2001, } 2007 \text { and } \\
2013 \text { respectively. Items (9) to (13) and (15) are as percentage to (8), (14) is a percentage of spot in net-gross terms; } \\
\text { FCY: Foreign currency; INR: Indian rupees; RDs: Reporting dealers } \\
\text { a All transactions involve exposure to more than one currency. } \\
\text { b Excluding "tomorrow/next day" transactions } \\
\text { c A swap is considered to be a single transaction in that the two legs are not counted separately. Including } \\
\text { "tomorrow/next day" transactions }\end{array}$} \\
\hline
\end{tabular}

The percentage of intervention to interbank turnover fell from 13.4 in 2001-02 to 0.9 in 2006-07, but it was still large compared to mature economies. The Bank of Japan intervened successfully in 2011 even with a percentage of 0.2 . This is the annual intervention percentage. The CB share can be much higher for daily intervention, which tends to be concentrated on a few days. Since the inter-bank market remains a large size of the total, the inter-bank share is not much higher than the percentage of $\mathrm{CB}$ intervention to total turnover. $\mathrm{CB}$ intervention, however, affected only domestic markets.

Even so, the derivative segment of the FX market also evolved. Cross- currency derivatives with the rupee as one leg were introduced, with some restrictions, in April 
1997. Rupee-foreign exchange options were allowed in July 2003. Exchange traded currency futures were started in $2008^{6}$. The most widely used derivative instruments were the forwards and foreign exchange swaps (rupee-dollar). As elsewhere, FX transactions were mostly OTC structured by banks. But there was user demand for liquid and transparent exchange traded hedging products, which are easier to regulate.

The non-deliverable forward (NDF) OTC market was growing because of large capital and trade flows, restrictions on FIIs ability to hedge in domestic markets, and larger spread between forward, futures and NDF markets. It began with diamond traders using it for arbitrage. In 2008 the Indian forward market was fairly liquid up to one year. The price movement in the near-term bucket reflected rupee liquidity in the interbank market and overnight interest rates but the six-month and one-year rates were determined also by expected future liquidity. Importers and exporters also influenced the forward markets. Forward rates in a particular segment could differ from other segments due to the excess supply/demand from importers/exporters in that segment.

The Clearing Corporation of India Ltd. (CCIL) set up by the Reserve Bank of India (RBI) in 2001 settled 90-95 percent of interbank rupee-dollar transactions. Foreign exchange trades were settled through multilateral netting thus saving transaction cost. All spot, cash, tom transactions and forward trades were guaranteed for settlement from the trade date reducing foreign exchange settlement and counterparty risk. A transparent FX dealing system, FX-Clear, of the CCIL launched in August 2003, decreased settlement risk and gave netting and operational benefits. It facilitated interbank trade through order matching and negotiation mode. Reuters platform was also available. Swaps and options were essentially inter-bank transactions, and accounted for about 50 percent of CCIL trade settlement (IMF, 2008).

The Reserve Bank moved gradually to eliminate restrictions on FX markets. Historically, the availability of hedging tools against foreign exchange risk was limited to entities with direct underlying foreign exchange exposures. However, with a larger set of economic agents exposed to foreign exchange risk there was a shift to

\footnotetext{
${ }^{6}$ In the absence of full rupee convertibility, a future contract could not result in the delivery of foreign currency. It was netted out in rupees, reducing its usefulness for hedging.
} 
the concept of "economic exposure", that is, the effect of exchange rates on a firm's value. There were gradual steps to give greater flexibility to corporates for managing their exposures. For example, it was proposed to permit agents to book forward contracts without production of underlying documents up to an annual limit of US \$ 100,000, which could be freely cancelled and rebooked. Cancellation and rebooking of forward contracts and swaps in India were regulated to reduce rupee volatility. There were moves to allow banks to fix their own net open position limits (NOPL) and AGL limits based on their risk appetite and ability to manage exposure, with adequate prudential regulation and supervision to cover systemic risk and prevent excessive leverage. By 2011, while banks boards set the NOPLs they had to be approved by the RBI.

\section{Box 2: The Process of Regulatory Change in India}

FX market regulations followed a dynamic process driven by regulatory objectives of market development with stability, demands from and requirements of markets. Some examples of this dialectic are given below, over 2002-13, a period with major changes in Indian FX markets.

Since 2002 persons resident in India were allowed to enter into forward contracts on the basis of underlying exposures. Further, exporters and importers were allowed to book forward contracts on the basis of declaration of exposures and based on past performances, subject to specified conditions. Permissions were slowly expanded, with the aim of enabling hedging through the reversal of a real transaction.

The annual Policy Statement for the Year 2007-08 (paras 142) provided greater flexibility to the Small and Medium Enterprises (SME) sector and resident individuals, further liberalization of the scope and range of forward contracts, to facilitate such entities to hedge their foreign currency exposures on a dynamic basis. There was a warning that authorized dealer (AD) Category - I bank should carry out due diligence regarding "user appropriateness" and "suitability" of the forward contracts to the SME customers. 
NRIs could now book forward contracts without production of underlying documents up to a limit of USD 100,000, based on self-declaration. These contracts would normally be on a deliverable basis. However, in case of mismatches in cash flows or other exigencies, the contracts booked under this facility could be cancelled and rebooked. The notional value of the outstanding contracts was not to exceed USD 100,000 at any time. Further, the contracts were permitted for tenors of up to one year only.

Source: RBI/2007-2008/, A. P. (DIR Series) Circular No. October 10, 2007

In an interview conducted in Sept. 2007, Mr. Bhaskar Panda - senior vice-president and regional head - treasury advisory group - HDFC Bank, assessed the changes and advocated further reform as follows:

Customized options have mostly evolved over the past 4-5 years after RBI liberalized its norms. Earlier, a corporate could hedge its risk only for 3 years, today they can hedge it for upto 10 years. But the value of the hedge is capped upto the basis of last year's turnover. Banks' want this regulation be altered to allow booking of forward contracts based on projected performances. Banks mostly trade on Reuters terminal, CCIL and voice brokers. Technology has made a big difference to the level of FX-dealing and has helped significantly to increase volumes.

CCIL was guaranteeing forward trades from the date they entered the spot window. But huge outstanding FX exposure and capital requirements still remained. Member banks wanted CCIL to extend guarantee to these trades from trade date itself. This would imply reduction in bilateral exposure between counter-party members; capital adequacy and balance sheet disclosure would be required only of net exposure in outstanding FX forward trades.

Source: Note on CCIL's website, Sept. 2007

Despite the GFC, the process of deepening FX markets continued. In 2008/09 futures were allowed and traded on exchanges. 
Changes proposed in the draft guidelines announced in Paragraph 119 of the Second Quarter Review of Monetary Policy for the Year 2009-10, Reserve Bank of India included:

1. Importers and exporters with foreign currency exposures in trade transactions, permitted to write covered call and put options both in foreign currency-rupee and cross currency and also to receive premia.

2. AD Category I banks permitted to offer plain vanilla cross currency options to persons residents in India (other than AD Category- I banks), who transform their rupee liability into a foreign currency liability.

3. Given the facilities given in item 1 the facility of zero cost structures/cost reduction structures was to be withdrawn, since these opaque structures were used for speculation on rupee strengthening and imposed large losses on firms in 2008.

17 January 2012: Hedging commodity risk on international exchanges allowed for listed companies through banks.

Reducing detailed oversight reduces transaction costs for firms, but the regulator has to prevent systemic risk. Although the strategy was to move from micro controls to regulating broad patterns, there was some back-tracking in times of high volatility. FX markets had deepened and the variety of hedging instruments increased, but the concern to increase the share of hedging transactions remained, as the assessment below from a market participant demonstrates:

Daily volumes in the currency futures market crossed US\$ 4 billion in just over a year after the launch. But over $70 \%$ of the volume traded came from jobbers and day traders. Open positions are an indicator of hedging. Banks and other players that arbitrage the OTC market accounted for another $12-15 \%$. So the open interest on the market from hedgers and medium-term position-takers was only about 12-15\%. Compare this to the CME, where open interest averaged nearly $95 \%$ of a daily volume of about $\$ 100$ billion a day. For an emerging market currency like the Mexican peso, greater hedging volume takes the ratio of open interest to volume to 300\% (Mecklai 
2010a). Since OTC transactions dominate, positions in futures markets alone are an insufficient gauge of hedging. But Rathinam and Aurora (2011) in a study of the off balance sheet activities of 15 Indian Scheduled Commercial Banks found that over 97 percent of notional amounts assigned to derivatives were for trading not for hedging.

Over 2011-13 there was some reversal in permissions due to global risk-off and excess rupee volatility and FX markets shrank somewhat.

\subsection{Types of intervention in FX markets}

Although the stated position remained the RBI would act to prevent excess volatility, markets were allowed to determine INR level and volatility subject to what remained of capital controls that were being reduced under domestic and international pressure. Intervention was temporarily suspended in 2007 at a time of strong inflows that made sterilization difficult, but resumed to accumulate inflows from October as the market stabilization bonds were negotiated for cost sharing with the government. The INR had to depreciate during post-Lehman equity outflows in order for them to take a write-down in asset values and share risk. The RBI did sell some reserves. Inflows resumed quickly, however, and upto end 2011, were just adequate to finance the CAD. So there was hardly any intervention in this period. This led to the market misperception that the RBI was unable to intervene in FX markets, aided by statements from the RBI about the large size of India's FX liabilities and potential capital movements relative to reserves. RBI communication was large-scale intervention was not possible since reserves even at 300 billion now just covered India's international liabilities. Just as policy allowed more market determination of the exchange rate becoming increasingly hands off, strong global risk-on risk-off in the period after the GFC created perverse movements in the exchange rate.

As inflows slowed due to global risk aversion after the Euro-debt crisis, markets shorted the rupee and it began to fall steeply, almost reaching 55. An environment of low growth and a rising CAD added to the fragility of FX markets. Measures to further liberalize inflows proved inadequate. So there was some reversal of liberalization - restrictions were put on FX markets and intervention resumed. RBI 
began to sell reserves in November 2011 as the INR spiraled downwards, and imposed restrictions on markets.

Retrospective taxation in budget 2012, and the Fed's taper announcement in May 2013, all led to outflows requiring RBI action ${ }^{7}$. Policy actions used included administrative measures such as controls, market restrictions, intervention or buying and selling in FX markets, signaling, and monetary policy measures such as the classic interest rate defense. Thus it turned out there were many feasible actions.

Table 1, which lists the policy measures taken over 2010-2014, attempts to assess their effectiveness by estimating this qualitative and quantitative impact on the exchange rate, that is, did a measure reverse or add to existing market movements and if so, by how much? The Table gives the basis points change in the INR/USD rate in the week before and the week after a measure. A negative entry implies an appreciation of the INR and a positive entry the reverse.

The Table indicates the most effective measure was the FX swap window ${ }^{8}$ announced for oil marketing companies on 28th August 2013. Not only did the INR strengthen substantially, but it reversed an existing depreciation. The peak value of INR/USD 68 was not regained. The rupee continued to appreciate after that, as other measures were added to the swap window that remained open till end November. Measures that made more FX available, such as the subsidy for banks foreign borrowing or easier ECB also appreciated the INR. Restrictions on markets such as reducing position limits worked only sometimes, and total bans were not effective (see also Section 2.3).

\footnotetext{
${ }^{7}$ After zero intervention from January, monthly net purchases in USD million were 10678 over 2007:10 to 2008:10. This switched to net sales of 1505 over 2008:11 to 2009:4 as outflows intensified under the GFC. Average intervention was near zero at monthly net purchases of 285 over 2009:05 to 2011:10. But 2011:10 to 2013:07 saw heavy monthly net sales of 8580.

${ }^{8}$ By entering into fixed tenor sell/buy USD-INR swaps through designated banks, the RBI effectively lent dollars against rupees with the transaction to be reversed in the future as the companies returned the dollars.
} 


\begin{tabular}{|c|c|c|c|}
\hline \multicolumn{4}{|c|}{ Table 1: Policy measures over 2010-2014 and effect on rupee (+depre, -appre) } \\
\hline Date & $\begin{array}{l}\text { Change in } \\
\text { INR/USD } \\
\text { (week before) }\end{array}$ & $\begin{array}{l}\text { Change in } \\
\text { INR/USD } \\
\text { (week after) }\end{array}$ & Policy action \\
\hline 28 December 2010 & -0.21 & 0.03 & $\begin{array}{l}\text { RBI issues guidelines for OTC FX derivatives } \\
\text { and overseas hedging }\end{array}$ \\
\hline 1 Feb. 2011 & 0.11 & -0.48 & Derivatives guidelines applied \\
\hline 15 September 2011 & 1.82 & 1.83 & $\begin{array}{l}\text { Exchange earners foreign currency account } \\
\text { and residents foreign currency accounts- } \\
\text { liberalization }\end{array}$ \\
\hline 15 November 2011 & 1.19 & 1.54 & $\begin{array}{l}\text { Increase in ceiling rate on banks' export credit } \\
\text { in foreign currency by } 150 \text { basis points }\end{array}$ \\
\hline 5 December 2011 & -0.77 & 2.18 & Speech reinforcing RBI's hands-off policy \\
\hline 15 December 2011 & 2.79 & -1.51 & $\begin{array}{l}\text { Bank net open position limits (NOPL) } \\
\text { reduced } 75 \% \text {; Free cancellation and } \\
\text { rebooking of FX forward contracts disallowed }\end{array}$ \\
\hline 21 May 2012 & 1.04 & 0.90 & $\begin{array}{l}\text { Netting of positions in currency futures/ } \\
\text { options with OTC positions disallowed; } \\
\text { position limits of banks for currency futures } \\
\text { and options reduced }\end{array}$ \\
\hline 11 Sept. 2012 & 0.07 & -1.18 & ECB policy eased \\
\hline 13 May 2013 & 0.96 & 0.12 & RBI restricts banks' gold imports \\
\hline 22 May 2013 & 0.89 & 0.58 & Bernanke says Fed may taper QE \\
\hline 20 June 2013 & 1.43 & -0.001 & $\begin{array}{l}\text { Foreign banks open positions in USD/INR } \\
\text { reduced to almost zero }\end{array}$ \\
\hline 9 July 2013 & 0.93 & -0.71 & $\begin{array}{l}\text { Any proprietary activity by banks in currency } \\
\text { futures banned }\end{array}$ \\
\hline 10 July 2013 & 0.72 & -0.42 & $\begin{array}{l}\text { Public sector oil companies directed to buy } \\
\text { FX only from one bank (SBI) }\end{array}$ \\
\hline 23 July 2013 & -0.36 & 1.43 & $\begin{array}{l}\text { Monetary tightening measures started from } \\
\text { July } 9 \text {; reduced LAF limit to } 0.5 \% \text { of a bank's } \\
\text { own NDTL; banks to maintain a daily } \\
\text { minimum CRR balance of } 99 \% \text {; MSF rate } \\
\text { raised to } 10.25 \text { and CMR moved up to it from } \\
\text { repo of } 7.25 \text {. }\end{array}$ \\
\hline 28 August 2013 & 4.63 & -2.32 & $\begin{array}{l}\text { FX swap window for oil companies (closed } \\
\text { end-November) }\end{array}$ \\
\hline 4 September 2013 & 1.36 & -3.24 & $\begin{array}{l}\text { Window for the banks } \\
\text { to swap the fresh } \\
\text { FCNR(B) deposits } \\
\text { with RBI and increase } \\
\text { in Banks' overseas } \\
\text { borrowing limit with } \\
\text { option of swap with } \\
\text { RBI }\end{array}$ \\
\hline 18 September 2013 & -1.07 & -0.92 & $\begin{array}{l}\text { Fed refrains from QE taper, keeps bond } \\
\text { buying at USD } 85 \mathrm{Bn}\end{array}$ \\
\hline 11 November 2013 & 1.89 & -0.74 & $\begin{array}{l}\text { Participation by SEBI registered FIIs, QFIs } \\
\text { long term investors in credit enhanced bonds }\end{array}$ \\
\hline 21 November 2013 & -0.63 & -0.80 & $\begin{array}{l}\text { Eased bank's use of swaps in negotiation of } \\
\text { loans from international/multilateral financial } \\
\text { institutions. }\end{array}$ \\
\hline 28 January 2014 & 1.36 & -0.54 & Fed reduces $\mathrm{QE}$ \\
\hline 3 September 2014 & 0.12 & 0.37 & $\begin{array}{l}\text { Relaxation of External Commercial } \\
\text { Borrowings (ECB) limits }\end{array}$ \\
\hline 28 October 2014 & -0.13 & 0.17 & Fed ends QE \\
\hline 28 November 2014 & -0.13 & -0.05 & $\begin{array}{l}\text { Oil prices plummet as OPEC refuses to cut } \\
\text { production }\end{array}$ \\
\hline
\end{tabular}


Raising interest rates to defend the rupee in July 2013 was a total failure. The rupee depreciated from around 60 in July to a low of 68 in August. The 3\% rise in shortterm rates was aimed at retaining debt flows since zero open positions ${ }^{9}$ already prevented domestic banks from speculating against the rupee. Ten per cent of the USD 6.6 that had come in since 2011 left in June after the May taper-on announcement. Higher short rates did not stop the outflows and by November $40 \%$ had left. Already high interest rate spreads and long-term rates rose, hurting the domestic recovery and domestic financial markets, where turnover fell further. Equity inflows, however, continued positive and were a healthy USD 14bn over 2011-13. Debt flows also revived by September 2013, after short term rates were normalized. Of the approximately USD 50bn FII inflows over 2013 and 2014, debt inflows were just a little over half.

Signals that the RBI was unable to intervene and the INR should be left to the markets in 2011 had a large counter-productive impact. Well-designed signals had the desired effect, as with the new RBI governor's joining and speech on September 4, 2013, announcing subsidies for banks raising FX deposits. Fed announcements also impacted the INR. It appreciated after the US Fed's $18^{\text {th }}$ September postponement of the taper.

The lessons from this experience were the importance of designing policy in line with the current state of capital account convertibility, restraints on debt flows, and evolution of markets. Given India's growth prospects and relatively greater reliance on growth driven equity flows, the interest rate defense was counter-productive and could have been avoided. The value of equity investors' assets decreases with a sharp depreciation, but an ineffective interest rate defense does not help existing equity investors, even as reduced growth harms new entrants. Even debt flows respond to risk premiums determined by overall macroeconomic stability, not just to narrow interest differentials.

\footnotetext{
${ }^{9}$ The net open position measures risks due to a banks' mix of buy and sell positions in different currencies. It is measured by the higher of net buy or net sell positions across all currencies. A zero open position means a bank cannot have foreign currency assets exceed foreign currency liabilities in its balance sheet or have an unsettled buy position in foreign currency. This reduces selling pressure on the rupee coming from banks.
} 
Under adverse expectation driven outflows the market demand and supply for FX will not determine an exchange rate based on fundamentals. Smoothing lumpy foreign currency demand in a thin and fragile FX market is important. Direct provision of FX to oil marketing companies was first used in the mid-nineties ${ }^{10}$. It is a useful way to temporarily provide FX reserves to a fragile market without supporting departing capital flows. It also encourages domestic entities to hedge. It showed there are innovative ways of using reserves. Oil companies return the dollars lent and reserves can be further built up during periods of excessive inflows. Although swaps add exchange rate risk to the RBI's balance sheet, it need not materialize over the short life of the swap if markets are successfully calmed.

In general, intervention must not be one-sided and has to be strategic, drawing on CBs superior aggregate market information. Timing is very important and must be based on market intelligence covering net open positions, order flow, bid-ask spreads (when one-sided positions dominate dealers withdraw from supplying liquidity and spreads rise), turnover, and share of interbank trades. Emerging markets (EMs) typically have less information and more uncertainty, so signaling can be effective. A variety of signals can be used.

It is only if these polices are not effective that restricting markets may become necessary. But that should be avoided, to the extent possible, since it has adverse sideeffects. Modeling strategic interaction between differentially informed speculators and the Central Bank, with EM features included shows why types of intervention and signaling that are not normally effective, may work in FX markets like those in India $^{11}$. Section 3 shows why bounds on exchange rate volatility can reduce noise trader entry poorly informed traders and thus improve policy autonomy. An EM is likely to have a larger share of such traders.

Each party is assumed to make inferences based on the other's behavior, under shocks that affect information extraction. The speculative demand curve is downward sloping in the spot rate and stable if there is greater uncertainty about fundamentals, or if

\footnotetext{
${ }^{10}$ I thank Dr. Y.V. Reddy for this point.

${ }^{11}$ This analysis is based on Goyal et. al. (2009).
} 
speculators prior on the target and CB's weight on the target are small. The first normally holds in an EM, and the second and third hold if the target is diffuse. The estimated speculative demand using data over 2002-08 was found to be downward sloping. CB purchase of dollars tended to depreciate the domestic currency, and reduced its volatility. Expectations were stabilizing and not perverse.

The results suggest a CB in an EM can optimally reveal some information, but should not announce an explicit target, or reveal its trading tactics. There is a range of possible signals. Greater uncertainty about fundamentals makes it more worthwhile for the $\mathrm{CB}$ to reveal some information about an exchange rate target.

As the model implies, market microstructure variables were found to affect intervention efficacy. Market microstructure variables such as merchant and dealer net demand (order flow) and turnover variables affected the level and volatility of exchange rates. Merchant turnover was a driving force, volatility and expected volatility increased dealer turnover. It follows microstructure variables matter and policy has a role in limiting volatility.

Anticipated intervention decreased turnover, so expectations from intervention were stabilizing and not perverse. They dampened rupee volatility. Since markets form expectations of intervention activity and respond strategically to it, more transparency may reduce the scope for such arbitrage. Although more transparency could reduce speculative positions, a diffuse target may work better. Estimated strategic market behavior and model derivations both indicated intervention and signaling to be an effective influence on exchange rates in the Indian context.

The interest rate differential had weak effects on the exchange rate but strong effects on market turnover. With the extant level of controls, the effect of the interest rate on the domestic cycle was stronger than its effect on the exchange rate. Given the evidence of the impact of policy on markets, more transparent intervention may effectively influence exchange rates in the Indian context, leaving interest rates free to target the domestic cycle. Next we turn to examining the efficacy of market restrictions in more detail. 


\subsection{Impact of measures on domestic markets}

The repeated scams and financial mishaps of the nineties demonstrated the fragility of a controlled system. Therefore financial reforms towards steady market deepening were undertaken. But the global financial crisis demonstrated the wisdom of India's slow and steady approach to market liberalization, and the necessity of prudential regulation to reduce risk-taking. Action on the INR was not, however, always consistent with these lessons. Sometimes actions were too hasty and cautious steps forward to deepen domestic markets were reversed, but did not always succeed in reducing rupee volatility.

On December 15, 2011 the RBI reduced banks net open position limits (NOPL) by 75\%. This forced MNCs banks to close their huge long USD positions. Bank boards did not want to have to report a fine paid to RBI for non-compliance. On representation the RBI clarified that genuine trade-based positions would be allowed. They also cancelled rebooking of forwards (corporates were shifting hedging band to 55-60, paying the option fee of 2 percent). These measures to reduce speculation by exporters and banks appreciated INR/USD from 54.2 to 52.7 (Table 1). The Rupee was back at 50 within a month.

Adverse tax measures in the March 2012 budget triggered outflows again and the INR again reached 55. Netting of positions in currency futures/ options with over-thecounter (OTC) positions was disallowed and position limits of banks further reduced in May 2012 but the next week saw the INR further depreciate by 0.90. Over June and July 2013 foreign banks open positions in INR/ USD was reduced to almost zero and any proprietary activity by banks in currency futures was banned, but depreciation continued. 


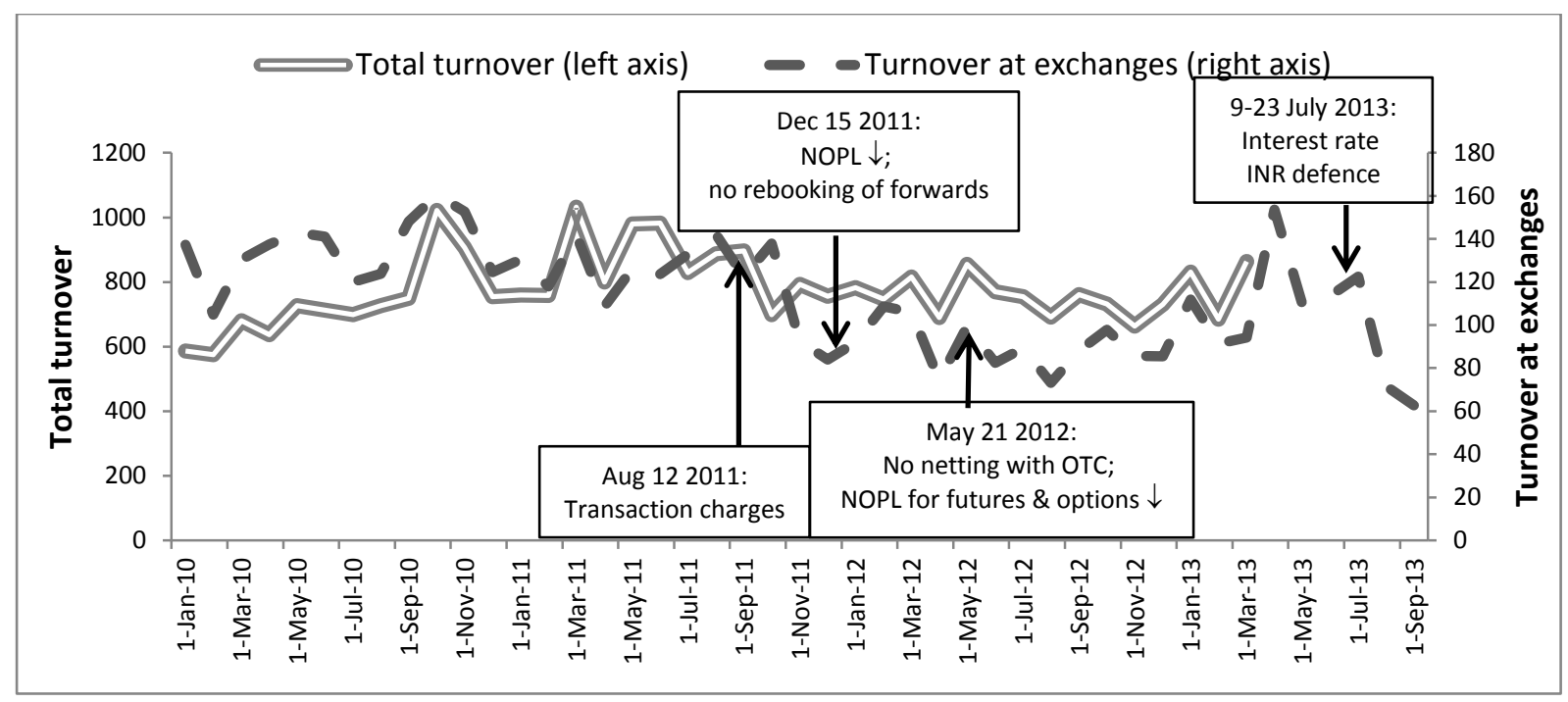

Figure 1: FX market turnover (USD billion)

Figure 1 shows various market restrictive measures reduced market turnover sharply in the currency derivatives markets in exchanges, while total turnover including the dominant over-the-counter (OTC) FX trading in banks also fell. This suggests the two types of markets are complements rather than substitutes. Banks are some of the largest traders on exchanges. Exchanges are thought to be dominated by speculative position-taking since no real underlying is required unlike in the RBI regulated OTC markets. But in FX markets worldwide portfolio rebalancing types of transactions between market makers are normally much larger than those based on real exposures. These allow banks, as well as small firms that may not get a good deal at banks, to lay-off risks in futures markets. Futures markets are more transparent and equitable but expectations are especially important in such markets and can lead to one-way positions, so prudential regulations are important.

\begin{tabular}{|c|c|c|c|c|c|c|}
\hline \multicolumn{7}{|c|}{ Table 2: Rise in cross border derivatives } \\
\hline & \multicolumn{6}{|c|}{ Total Outright Forwards } \\
\hline & \multicolumn{3}{|c|}{ Domestic: net-gross basis } & \multicolumn{3}{|c|}{ Global INR: net-net basis } \\
\hline & $\$ \mathrm{~m}$ & $\begin{array}{l}\text { Cross } \\
\text { border \% }\end{array}$ & $\begin{array}{l}\% \text { of } \\
\text { spot }\end{array}$ & $\$ \mathrm{~m}$ & $\begin{array}{l}\text { Cross } \\
\text { border \% }\end{array}$ & $\%$ of spot \\
\hline Apr-13 & 3,743 & 14.64 & 24.19 & 24,395 & 60.43 & 160.23 \\
\hline Apr-10 & 4,895 & 8.56 & 36.50 & 13,620 & 52.11 & 100.69 \\
\hline
\end{tabular}


The other effect of restrictions was offshore markets grew at the expense of domestic markets. In more open regimes, restricting domestic markets encourages transactions to migrate abroad. Though an accurate assessment of the volumes is difficult, estimated daily INR NDF turnover was around US \$ 100 million in 2003/2004 and grew substantially since. By April 2013 it exceeded onshore trading ${ }^{12}$. Onshore market affects price discovery in INR NDF market. However, in volatile market conditions NDF markets influence spot and forward onshore markets. A large spread between INR NDF rate and INR futures/forward rate impacts the spot rates significantly. The INR forward rate is influenced by the movement of INR NDF futures and spot rates with some lag (Behera, 2011). Although such markets create problems for policy, they normally wither away as domestic markets deepen (Ho and McCauley, 2004).

Although they are difficult to measure precisely BIS (2010 Table E6, 2013 Table 6.3) shows OTC INR turnover (net-gross basis) outside the country rose from 50\% (20.8 USD bn) in 2010 to $59 \%$ (36.3USD bn) in 2013 of the total turnover. Table 4.2 shows the sharp rise in INR forwards, which include NDF, between 2010 and 2013 when domestic restrictions were imposed. The rise as well as much higher net-net compared to net-gross value shows much of the growth was abroad ${ }^{13}$. A rising share of the nondeliverable forward market is against the objective of developing and deepening domestic markets. Moreover, domestic regulators are unable to influence offshore markets. Therefore using prudential regulations instead of forbidding transactions, would also have the advantage of not driving markets overseas.

\subsection{Encouraging hedging}

A conviction of possible two-way movement of the exchange rate, large enough to deliver a substantial loss to one-way bets is a pre-requisite for hedging or the laying off of currency exposure. Despite deepening FX markets, the moderate two-way movement within an implicit 5\% band seen over 2004-06 was not sufficient to overcome strong expectations of medium term appreciation given India's high growth

\footnotetext{
${ }^{12}$ Mecklai (2011) argues it had become higher even by 2011.

${ }^{13}$ It is noteworthy that the relative size of forwards in net-net global GBP trade and net-gross trade in UK is reversed for the deepest FX market, UK. In April 2013, the net-gross at USD 309bn was much larger than net-net at USD 69 bn. FX trade in the UK is very large in currencies other than the GBP, including the INR. It follows a large share of transactions involving the INR occur abroad. Relative turnover sizes for other EMs are like that for India.
} 
rate. In 2007, market expectations of the INR/USD rate had even reached 32. Many corporates borrowed abroad based on such expectations, increasing currency risk. Some had entered into so called hedging deals, which were actually bets on the value of the Swiss Franc. With the volatility in currency markets and steep rupee depreciation in 2008 many firms lost money. Many such deals, where Indian banks were often a front for foreign banks, sidestepped existing rules that prevented leverage or underlying risk that exceeded export income. Although firms were not allowed to write options deals were structured so that in effect firms were writing options. The deals were so complex that firms sometimes did not understand what risks they were taking. After post GFC episodes of excess volatility, the rupee was managed and stayed in a tight band of INR/USD 64-66 over September 2013-December 2014. Since international interest rates were much lower than Indian rates firms were again tempted into unhedged foreign borrowing, although such borrowing, for example, through ECB, was capped. Even so, gross ECBs worth around USD 264.4 bn came in from 2001 until Oct 2014. Refinancing takes up a large share ${ }^{14}$. Not hedging is dangerous since the bulk of the borrowing was by infrastructure firms that do not have any natural hedge in the shape of exports.

Thus availability of more instruments, alone, only makes leveraged speculation, or bets on future currency value, possible. Establishing inducement to hedge through sufficient flexibility of the exchange rate, along with transparency, clarity and information, and strategic use of controls, are more important (Shiller, 1993, Shefrin, 2002). Completing markets will not by itself reduce speculation. Incentives have to be changed, and better information provided on fundamentals.

\section{FX Markets and Policy}

Well-designed signals can help use the structure of FX markets with varying trader information levels to achieve policy objectives such as reducing exchange rate volatility. An EM is likely to have a larger share of poorly informed traders.

Jeanne and Rose (2002) have a model with informed and noise traders (n) in an FX market. The benefit of entry for noise traders rises with excess returns or risk, $\rho$, but

\footnotetext{
${ }^{14}$ For example, of the USD 2.8bn that came in October $201428 \%$ was for refinancing.
} 
falls with the variance of the spot rate, var (S). But both $\rho$ and var (S) are functions of $n$. A rise in $n$ lowers $\rho$ since a larger number of traders are demanding the currency thus spreading risk; but raises var (S) since entry raises volatility and therefore risk. Both reduce entry. But the rise in var $(\mathrm{S})$ itself raises $\rho$, thus increasing entry. Noise traders therefore have two counteracting roles. They both create risk and share risk, making multiple equilibria possible.

This can be shown in a simple diagrammatic device following Goyal (2006). G(n), the function giving the returns to noise trader entry is graphed against $n$ in Figure 4.3. The two opposing effects of $n$ on G(n) give the curve the shape shown in the Figure (derived in the appendix). At low $n \mathrm{G}$ is high since var (S) is low. It falls as more $n$ share risk reducing $\rho$. But further entry creates risk raising var $(\mathrm{S})$ and $\rho$. At high $n \mathrm{G}$ rises again, as the rise in $\rho$ dominates that in $\operatorname{var}(\mathrm{S})$.

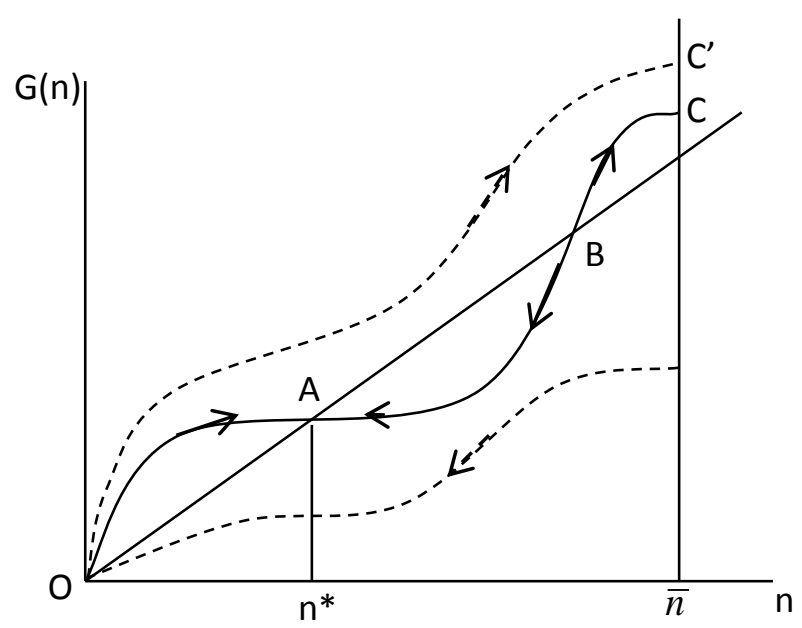

Figure 3: Entry of noise traders in FX

The lowest dashed curve is the case where fundamentals are strong. Therefore excess returns are so low that it is not worthwhile for any noise trader to enter. Point $\mathrm{O}$ is a stable equilibrium, as is C', on the upper dashed curve. On this curve, fundamentals are so weak that all the noise traders enter. Multiple equilibria occur for intermediate fundamentals when $G(n)$ is such that it cuts the $45^{\circ}$ line. These are equilibria since $G$ $=\mathrm{n}$ at these points. $\mathrm{A}$ is stable since for a small departure from $\mathrm{A}$, net returns are such as to bring entry back to $\mathrm{n}^{*}$. C is also stable. But B is unstable. Here the curve cuts the 
$45^{\circ}$ line from below ${ }^{15}$. So a small rise in $n$ raises returns and induces more entry until

$\mathrm{C}$ is reached. A small fall in $n$ reduces returns and entry until $\mathrm{A}$ is reached.

At $C^{\prime}$ and $\mathrm{C}$ all noise traders enter. At A, $\operatorname{var}(\mathrm{S}), \rho$ and therefore entry $n$ are all low; at $\mathrm{C} \operatorname{var}(\mathrm{S})$ and $\rho$ are both high and maximum entry $\bar{n}$ takes place. Between $\mathrm{AB}$, since $\mathrm{G}(\mathrm{n})<n$, entry falls back to $n^{*}$ at $\mathrm{A}$; between $\mathrm{CB}$, since $\mathrm{G}(\mathrm{n})>n$, entry rises and $n$ increases to $\bar{n}$ at $\mathrm{C}$. Therefore $\mathrm{O}, \mathrm{A}, \mathrm{C}$ and $\mathrm{C}^{\prime}$ are stable equilibria, while $\mathrm{B}$ is unstable. It follows exchange rate volatility can be low if fundamental variance is low, but it can be either high or low for intermediate levels of fundamentals.

Monetary policy can improve welfare if it leads to the selection of low volatility equilibria. It can do this by committing to $\operatorname{var}(\mathrm{S}) \leq \mathrm{v}$. Then fewer $n$ enter, this decreases $\operatorname{var}(\mathrm{S})$ leading to the selection of the low entry equilibrium $\mathrm{A}$. This is a policy free lunch since markets help monetary policy achieve the reduced volatility it had committed to.

A stable exchange rate regime, where policy constrains var(S) to be less than or equal to $v$, leads to lower entry of noise traders taking the economy to an equilibrium with low exchange rate variance ${ }^{16}$. Although there is a loss of monetary autonomy in adopting the restriction on $\operatorname{var}(\mathrm{S})$, the loss is of second order, as the level of noise in the economy is decreased. Monetary policy response function is constrained out of equilibrium, but there is no sacrifice of monetary autonomy in equilibrium. In the post GFC period Indian exchange rate volatility was allowed to rise too much, while there were also periods when it was too low. Goyal and Arora (2012) give evidence CB speeches affect the exchange rate but over the period signals were poorly used. Table 4.1 shows this in 2011 but indicates improvement in 2013.

\section{Conclusion}

\footnotetext{
${ }^{15}$ The style of proof is similar to the well-known Keynesian cross where the aggregate demand line cuts the $45^{\circ}$ aggregate supply line from above in a stable equilibrium. The intuition is similar in the fixed point theorems used in general equilibrium theory. The proof following Goyal (2006), a major simplification of that used in Jeanne and Rose (2002), is given in the Appendix.

${ }^{16}$ Such an induced entry of noise traders was illustrated by the large-scale shorting of the INR in December 2011 after the CB's communications were taken to imply it would not intervene to support the rupee.
} 
The paper gives an overview of international and Indian FX markets and discusses market microstructure concepts such as 'order flow', bid-ask spreads, limit order, novation, netting, settlement and counter-party risk, electronic broker and crossing systems, inventory risk and 'hot potato' trading. It also records the very large size of FX transactions and the growth and deepening of Indian FX markets aided by steady regulatory changes. OTC and bilateral transactions dominate in FX markets, but it is not yet clear if technological changes and the international post global crisis regulatory emphasis on transparency will lead to more exchange trading. It may be that FX markets are fundamentally different, with the bilateral market structure essential for stability.

It also draws out the implications of structure for CB intervention, signaling, and exchange rate policy especially in an EM. Committing to a low exchange rate volatility regime provides something like a free lunch to monetary policy, because, as the analysis in the last section showed, entry of noise traders is reduced leading to lower volatility. In an EM there tends to be greater uncertainty about fundamentals. This tends to make the speculative demand curve well behaved under strategic interaction between differentially informed speculators and the Central Bank (CB). A diffuse exchange rate target and strategic revelation of selected information can be expected, therefore, to be effective. Indian experience supports these results.

Post GFC experience even delivers an effectiveness ranking of policy actions influencing the exchange rate at the current state of capital account convertibility. The most effective is to address fundamental weaknesses that can trigger adverse expectations, but second, reserves and signaling can be used to smooth market demand and supply keeping the exchange rate within bounds. The efficacy of building-up reserves, using them in targeted intervention, and of credible communication to markets was clearly demonstrated. Since capital flows do not always match the net import gap, a CB should be ready to close any short-term demand supply mismatch. Reserves can be built up again during periods of excessive inflows.

Prudential measures such as reducing open positions worked better than a ban on a market or a transaction-type. But it reverses attempts to deepen markets and leads to a 
migration of activity abroad. If market restrictions become necessary, therefore, they should be carefully targeted. Even if credit curbs are used they should apply only to specific commodities such as gold imports. Since these administrative measures reduce one-way positions, a general liquidity squeeze such as an interest rate defense that hits other markets, should be avoided. EMs should continue the push for greater global policy coordination and measures that reduce the financial over-leverage that leads to capital flow volatility, even while developing regional safety nets.

\section{References}

Lyons, R.K. 2001. The Microstructure Approach to Exchange Rates, Cambridge, MA: MIT Press.

BIS (Bank of International Settlements). 2013. 'Triennial Central Bank Survey of foreign exchange and derivatives market activity in 2013'. December, and earlier reports. http://www.bis.org/publ/rpfx13.htm.

Caballero, R. and A. Krishnamurthy. 2004. 'Smoothing sudden stops'. Journal of Economic Theory. 2001 working paper version http://www.nber.org/papers/w8427

Geithner, T. J. 2004. 'Hedge funds and their implications for the financial system'. Federal Reserve Bank of New York. Available at http://www.newyorkfed.org/newsevents/speeches/2004/gei041117.html

RBI. 1995. 'Report of the expert group on foreign exchange markets in India' (Sodhani Committee Report). June. Reserve Bank of India: Mumbai.

Tarapore, S.S. 2006. 'Report of the committee on Fuller capital account convertibility’. Reserve Bank of India: Mumbai

IMF. 2008. 'India: selected issues'. IMF Country Report No. 08/52 January. International Monetary Fund: Washington.

Hart, O.D. and D.M. Kreps. 1986. 'Price destabilising speculation'. Journal of Political Economy, 94 (5), pp: 927-952.

Burnside, C., M. Eichenbaum, S. Rebelo. 2001. 'Hedging and financial fragility in fixed exchange rate regimes'. European Economic Review, 45, pp: 1151-1193.

Jeanne, O., and A.K. Rose. 2002. 'Noise trading and exchange rate regimes.' The Quarterly Journal of Economics, 117 (469), pp: 537-570.

Goyal, A. 2015. 'External Shocks', Chapter 3 in S. Mahendra Dev (ed.), India Development Report 2015, New Delhi: IGIDR and Oxford University Press, pp. 3651. Earlier version available at http://www.igidr.ac.in/pdf/publication/WP-2014046.pdf. 
Goyal, A. 2006. 'Exchange rate regimes: middling through'. Global Economic Review, 35 (2), pp: 153-176. June.

Goyal, A. and S. Arora. 2012. 'The Indian Exchange Rate and Central Bank Action: An EGARCH Analysis', Journal of Asian Economics. 23(1), February, 2012.

Goyal, A., R. A. Nair and A. Samantaraya. 2009. 'Monetary policy, forex markets, and feedback under uncertainty in an opening economy'. Development Research Group, Department of Economic Analysis and Policy, Mumbai, Study No. 32. Available at http://rbidocs.rbi.org.in/rdocs/Publications/PDFs/DRGMP030909.pdf

Mecklai, J. 2010a. 'Market Maniac: Bringing hedgers to the futures market, Business Standard, January 8. Available at http://www.businessstandard.com/article/opinion/jamal-mecklai-bringing-hedgers-to-the-futures-market110010800002 1.html

Mecklai, J. 2010b. 'Market Maniac: The OTC-FX market—Falling behind the curve', Business Standard, October 1. Available at http://www.businessstandard.com/article/opinion/jamal-mecklai-otc-fx-market-falling-behind-the-curve$\underline{110100100093 \text { 1.html }}$

Mecklai, J. 2011. 'Market Maniac: Has RBI lost control of the rupee?', Business Standard, July 1. Available at http://www.businessstandard.com/article/opinion/jamal-mecklai-has-rbi-lost-control-of-the-rupee$\underline{111070100044 \_1 . h t m l}$

Rathinam, F. X. and D. Arora. 2011. 'OTC derivatives markets in India: recent regulatory initiatives and open issues for market stability and development'. Macroeconomics and Finance in Emerging Market Economies, 4 (2), pp: 235-261. September. Available at http://www.tandfonline.com/doi/pdf/10.1080/17520843.2011.580571.

Sager, M.J. and M. P. Taylor. 2006. 'Under the microscope: the structure of the foreign exchange market'. International Journal of Finance and Economics. 11, pp: 81-95.

Ma, G., C. Ho and R. N. McCauley. 2004. 'The markets for non-deliverable forwards in Asian currencies'. BIS Quarterly Review, pp: 81-94. June.- Not referred

Behera, H. 2011. 'Onshore and offshore market for Indian rupee: recent evidence on volatility and shock spillover'. Macroeconomics and Finance in Emerging Market Economies, 4 (1), pp: 43-55.

Shefrin, H. 2002. Beyond Greed and Fear: Understanding Behavioral Finance and the Psychology of Investing. Oxford: Oxford University Press. .- Not referred

Shiller, R.J. 1993. Creating Institutions for Managing Society's Largest Economic Risks, Clarendon Lectures in Economics, Clarendon Press: Oxford. .- Not referred 


\section{Appendix: Deriving equilibrium noise trader entry}

Equilibrium requires that a constant number of noise traders, $n$, enter. Noise trader's benefit from entry rises with $\rho$ and fall with $\operatorname{var}(\mathrm{S})$. Entry will occur only as long as this benefit exceeds their cost of entry. Equation (A.1) defines an implicit, smooth twice-differentiable benefit function:

$$
B(\rho, \operatorname{var}(S)) ; \quad B^{\prime}[\rho]>0, \quad B^{\prime}(\operatorname{var}(S))<0
$$

Where a superscript dash indicates a partial derivative. Trader $\mathrm{j}$ will enter the market as long as:

$$
B(\rho, \operatorname{var}(S)) \geq c_{j}
$$

But both $\rho$ and $\operatorname{var}(\mathrm{S})$ are functions of $n$. Equilibrium $\rho$, equates demand to supply in the domestic currency security market. It is given by equation (A.3), written implicitly as:

$$
\rho^{*}=\rho(\operatorname{var}(S), n) ; \quad \rho^{\prime}(\operatorname{var}(S))>0, \quad \rho^{\prime}(n)<0
$$

A superscript $*$ denotes an equilibrium value. Similarly, the equation for equilibrium $\operatorname{var}(\mathrm{S})$ is written implicitly as:

$$
\operatorname{var}(S)^{*}=\operatorname{var}(S)(n) ; \quad \operatorname{var}(S)^{\prime}(n)>0
$$

In equilibrium either all noise traders will enter, or none will enter, or some will enter, so that $n \in[0, \bar{n}]$. If $\mathrm{B}()>\mathrm{c}_{\mathrm{j}}$ for all noise traders, all will enter. If $\mathrm{B}()<\mathrm{c}_{\mathrm{j}}$, no noise trader will enter. In an equilibrium with interior values, (A.2) will hold with equality, and $\bar{\rho} *$ and $\operatorname{var}(\mathrm{S})^{*}$ will take critical values such that the marginal noise trader is just indifferent to entering.

$$
B\left(\rho^{*}, \operatorname{var}(S)^{*}\right)=c_{j}
$$

At $\rho<\rho *$ or $\operatorname{var}(S)>\operatorname{var}(S)^{*}$, benefits to entry are lower than at equilibrium so $n$ will shrink. Since both $\rho$ and $\operatorname{var}(\mathrm{S})$ depend on $n$, a function $\mathrm{G}(\mathrm{n})$ can be defined, that determines entry: $G(\rho(\operatorname{var}(S), n), \operatorname{var}(S)(n))$. If $n \neq \mathrm{G}(\mathrm{n})$ it cannot be an equilibrium. Hence equilibrium entry is:

$$
n^{*}=G\left(\rho\left(\operatorname{var}(S), n^{*}\right), \operatorname{var}(S)\left(n^{*}\right)\right)
$$

If $\mathrm{B}()>\mathrm{c}_{\mathrm{j}}$ then $\mathrm{n}<\mathrm{n}^{*}$, noise trader entry will occur and $n$ will rise. Since $\rho$ falls with $n$ but rises with $\operatorname{var}(\mathrm{S})$, and $\operatorname{var}(\mathrm{S})$ rises with $n$, multiple equilibria are possible. $G^{\prime}(\rho)>0$ and $G^{\prime}(\operatorname{var}(S))<0$, therefore although $\mathrm{G}(\mathrm{n})$ can be high since var (S) is low it falls with $n$ at low $n$ as $\rho$ also falls and decreases $\mathrm{G}(\mathrm{n})$. The risk sharing function 
dominates. But at high $n$, the positive effect of $n$ on $\operatorname{var}(\mathrm{S})$ and therefore on $\rho$ will dominate $-\rho$ will rise as risk rises. Hence $\mathrm{G}(\mathrm{n})$ will also rise with $n$ at high $n$. Therefore equilibria are possible both at low and at high $n$. Either a few or a large number of noise traders will enter the FX market. But, in each equilibrium $n$ takes a fixed value, given by the function $G(n)$. Noise traders create risk so $\operatorname{var}(S)$ rises and $\rho$ falls with their entry $(n)$. But $\rho$ also rises with $\operatorname{var}(\mathrm{S})$, since they also share the risk they themselves create. 